\title{
Integrating Digital Literacy Into EFL Classroom: A Study of Theory of Planned Behavior
}

\author{
Nurul Alfia ${ }^{1 *}$, Sumardi ${ }^{2}$, Diah Kristina ${ }^{3}$ \\ 1,2,3 Pendidikan Bahasa Inggris, Universitas Sebelas Maret, Surakarta, Indonesia \\ *e-mail: nurulalfia18@student.uns.ac.id
}

\begin{abstract}
Beliefs take a vital role in influencing students' decision about integrating digital literacy in EFL classroom. This case study investigated students' behavioral, control, and normative beliefs toward integrating digital literacy into the EFL classroom. This research used the Theory of Planned Behavior initiated by Ajzen to collect and analyze the data. The results of interviews and observations highlighted students' integration of digital literacy into EFL classroom referred to several beliefs. The behavioral beliefs (attitude toward advantages of a behavior) about the value of digital literacy for its effectiveness and efficiency potential to find information, to promote students cognitive skills and ethical awareness, and to improve English proficiency; normative beliefs (about social support) about the meeting of the expectation of school, teachers, parents, and friends; and control beliefs (about perceive behavioral control) about the opportunity and the availability to interact with the technology. This study highlighted a substantive theory related to the findings: Students' positive beliefs about integrating digital literacy into EFL classroom influence students' learning strategy. By having positive beliefs about the outcomes that students will get (behavioral beliefs), support from family, teachers, and the school environment (normative beliefs), as well as beliefs about the presence of factors that may facilitate or hinder the performance (control beliefs), students demonstrate the tendency to always use digital technology in learning English.
\end{abstract}

Keywords: Digital Literacy, Students' Beliefs, Planned Behavior

\section{Introduction}

The rapid development of digital technologies followed by the Internet's development allows anyone to obtain and create information quickly and without limits. As a result, not all Internet information is valid and reliable; this phenomenon should be addressed wisely. This phenomenon requires internet users who are dominated by high school age teenagers to require special skills consist of the skills to find, understand, evaluate, use, communicate, and create information obtained through all digital sources by involving sociological and emotional abilities (Eshet-Alkalai, 2012; lordache et al., 2017; Payton \& Hague, 2010). This ability is known as digital literacy. In the educational dimension, digital literacy was considered a set of skills that claimed to be able to improve students' higher-order thinking skills such as analysis, cooperation, and creation to bridge students to access more accurate and credible information quickly and easily. Digital literacy is one of the skills that must be possessed in the 21st Century (Bekker et al., 2015). By having digital literacy, students are expected more than just equipping oneself with the technical skills to operate digital devices, tools, software and hardware, and surfing the Internet, but instead comprises a set of knowledge, competencies, and attitudes needed to become functional in a digital era (Ferrari, 2013). In other words, digital literacy is utilized as a students' guide and filter in accessing the digital device in the digital era.

Realizing the urgency of digital literacy in education, teachers started to involve digital technology to encourage students to integrate digital literacy in the school environment. Prior studies integrated digital literacy into teaching and learning activities, especially in language learning (Ng, 2012; Hafner et al., 2015; Bekker et al., 2015). The success of teaching and learning language process is affected by teachers' and students' beliefs about language

\footnotetext{
${ }^{*}$ Corresponding author.

Received November 09, 2021; Accepted April 10, 2021; Available online September 25, 2021

Copyright @ 2021 by Author. Published by Universitas Pendidikan Ganesha.
}

Jurnal Pendidikan Indonesia (JPI) | 535 
learning and attitude as well as digital literacy (Cephe \& Yalcin, 2015; Furinghetti \& Pehkonen, 2005). The student's belief in learning refers to the assumptions and indirect comprehension of students towards learning. The assumptions and comprehensions in question include meanings about learning, expectations about what should be taught, and teachers and students' role in education (Chan \& Elliott, 2004). Students' beliefs contain affective and emotional elements related to how students perceive their learning environment. This perception then influences their approach to learning and learning outcomes (Karagiannopoulou \& Christodoulides, 2005). Previous study codified these beliefs into three types; behavioral beliefs, control beliefs, and normative beliefs (Ajzen, 1991). These beliefs are contained in a theory known as the theory of planned behavior (TPB). The main factor in this theory is the individual's intention to take action. The intention is assumed to be a determinant of motivation, which will then influence behavior; this will determine how hard someone tries to try and how much effort they will spend on doing that action. The stronger the intention, the greater the effort. However, it must be clear that behavioral intentions can bind expressions in behavior only if the behavior is under control.

Behavioral belief is an individual's assumption of the values of a behavior (positive behavior). If an individual has positive behavior towards behavioral beliefs, then there is a possibility that someone will carry out these behaviors. For example, in this case, if students think that integrating digital literacy in learning media can improve the quality of learning outcomes (positive behavior), they will do so. Meanwhile, normative beliefs relate to the assumption of support given by certain people, groups, or the environment for specific actions. If students are in a supportive environment to carry out a behavior, then the social pressure to carry out behavior will be felt, and vice versa. Perceived behavioral control refers to an individual's perception of the ease or difficulty of performing attractive behaviors (Ajzen, 2005). Based on the theory of planned behavior, control beliefs are the basis for measuring perceived behavior control. Control belief shows that the more confident students are in their abilities and access to resources, the more control they feel (Sadaf \& Johnson, 2017).

Many previous studies have explored the beliefs and intentions related to the integration of digital literacy by practicing teachers in their classrooms (Sadaf \& Johnson, 2017), parents and teachers intentions to the use of digital media for family-school communication (Bordalba \& Bochaca, 2019), and language learners' intention to attend a class and learn a foreign language in face-to-face and online settings (Alhamami, 2018) using the theory of planned behavior, but the research that explores student beliefs in integrating digital literacy in the EFL classroom using the Theory of planned behavior asthe framework is still limited. Consider these limitations; this study aims to provide insight into the beliefs of native digital students with regard to their integration of digital literacy into EFL classrooms, and teachers, schools, and parents' understanding of the need for professional development to better support students in integrating digital literacy into their EFL classroom. The need for practicing digital literacy to adolescents is vital because the beliefs of students affect their action.

Moreover, adolescents are considered the most vulnerable group to receive the most dangerous digital media effects. However, knowing students' beliefs can provide useful information about its vital role in learning, such as influencing students' learning outcomes (Furinghetti \& Pehkonen, 2005), motivation, and learning strategies (Richards \& Lockhart, 1994). Moreover, in language learning, students' beliefs affect their motivation, attitude, achievement, proficiency, anxiety, success, behavior, and strategy in learning the language (Abdi \& Asadi, 2015). This research aims to investigate students' behavioral beliefs, normative beliefs, and control beliefs in the integration of digital literacy into EFL classroom.

\section{Method}

This research implied a qualitative case study approach. The researchers held the Classroom observation and online open-ended questionnaire to find-out students' beliefs about the integration of digital literacy into EFL classroom, it coincided that when the researcher had the classroom observation, the students were about to learn and design 
brochure as the project of specific sub-theme learning. Meanwhile, the data triangulation obtained semi-structured interviews. This research arranged purposive sampling and recruited 24 senior high school students in eleventh grade (around 16 years old) as participants and three of them as an informant to answer in-depth interview. Thus, these young learners were expected to have relatively high skills in the use of digital technology. All participants in the class were allowed to bring a smartphone or laptop (if needed) connected to the internet network, whether it was connected to the WiFi provided by the school or using personal mobile data. In addition, all participants were active internet users who used it as a media to connect with others (social media) or as a media to help them learn English.

This paper employed a constant comparative method (CCM) as the methodology to analyze the data. The phase of CCM is districted into four stages: determining information, categorizing, determining the relationship between information categories, and writing the theory (Glaser \& Strauss, 1967; Lincoln \& Guba, 1985). In the beginning, the data relating to the research were gathered and processed, while other unrelated findings were discarded. In this study, the processed data was obtained from observation and semi-structured interviews about students' beliefs about the integration of digital literacy into the EFL classroom. Data collected from observations and interviews were categorized based on its similarities; by transcript, coded, and generated the data. In this study, the data were grouped into three groups; behavioral beliefs, normative beliefs, and control beliefs. At the determining the relationship between information categories stage, all annotated concepts were examined to see whether they have been classified in the relevant category and whether or not this category had become saturated. In the end, the theory was drawn as the final result of the study.

\section{Result and Discussion}

\section{Results}

\section{The students' behavioral beliefs}

Behavioral beliefs' main idea is to identify students' belief in what values (benefits) they might get if they integrate digital literacy in instructional media (Ajzen, 1991). The intended value or service relates to how digital literacy helps them learn or not. These values were related to information effectiveness, cognitive skills and ethical awareness, and English proficiency. Based on Figure 1, it can be seen that students' beliefs in integrating digital literacy in English class in the aspects of belief were quite firm. It means students believe that integrating digital literacy into instructional media can bring value. Toward this entity, most of the students effectively had positive beliefs on integrating digital literacy into the EFL classroom.

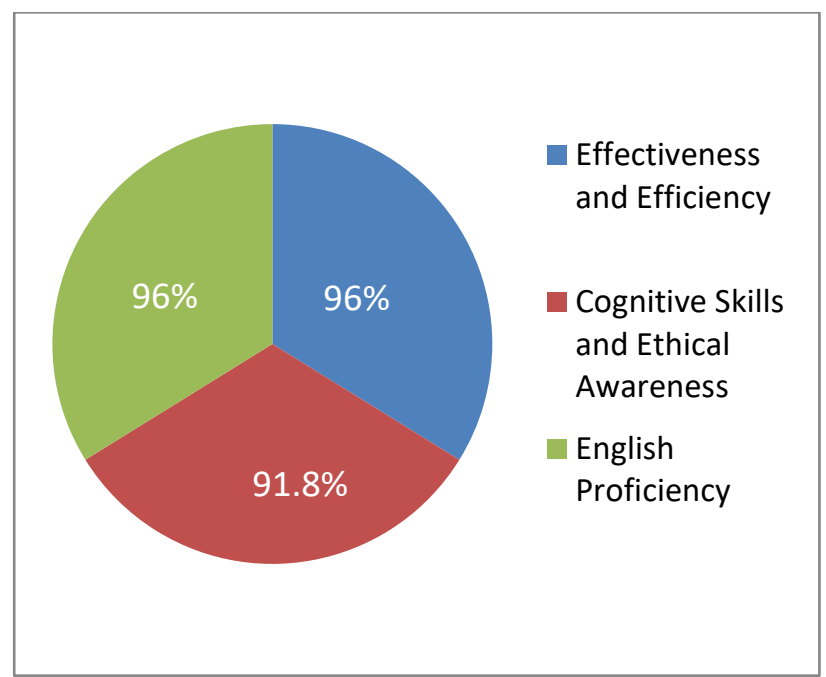

Figure 1. Close-ended questionnaire result of students' behavioral beliefs about the integration of digital literacy into EFL classroom 


\section{The effectiveness and efficiency}

The first category of questionnaire initiated to negotiate students' value beliefs toward the effectiveness and efficiency of seeking information toward the Internet. Based on the result shown in Figure 1,96\% of students have positive beliefs in integrating digital literacy into instructional media in EFL calssroom. The reason behind the positive perception relates to ease of access and save more time. A students said that finding information through the Internet was easier. All the user need was to submit the keyword to the search engine (google), and the information needed will appear in second. Therefore, it could save time. Similarly, another informan mentioned that searching for information through the Internet was more practice, and complete because it contains more complete information than book. Meanwhile, another student claimed that there was an amount of information provided on the Internet. Considering the effectiveness and efficiency especially in terms of accessability, students prefer to seek for information trough digital technology.

\section{Cognitive Skills and Online Ethical Awareness}

The next issue explores students' believe that integrating digital literacy into instructional media increased their cognitive skills and online ethical awareness. The positive perception is proved by $91.8 \%$ of students have positive beliefs about integrating digital literacy into instructional media will facilitates them in increasing their ability to understand, compare, analyze, evaluate, communicate, create information both in form of illustration or text, and improve their self-awareness about internet ethics. This finding is supported by interview data that revealed that students have no difficulties in understanding information presented in the form of text and illustration (icons, pictures, tables, or diagram. The information presented in simple language and sometimes followed by illustrations influenced students' better understanding of the information. In addition, students realize that there was a variety of information available on the Internet, but not all information was reliable. Broad and diverse information forces students to analyze and think critically about the information received. By integrating digital literacy, students believed that they can select credible and valid information. In order to find reliability and credibility of information, the interviews revealed that students often compared information from several websites and relying on the trusted website recommended by their teacher or maintained by well-known English course institution, then analyzed and evaluated the information.

Meanwhile, in terms of communication, integrating digital literacy facilitates students to express, convey, and share information through various digital media forms. The interview data revealed that due to its potential to exchange information faster and easier, students prefer to utilize the digital technology to share useful information they got with others, sent assignments, and discusses via digital. As the digital native generation, students preferred to focus on the efficiency and effectiveness of digital literacy. The next issue explores students' cognitive skills in terms of creativity. Students utilize digital technologies such as Canva and others online platform in designing brochures. To this entity, most of students feel more creative in creating a new product such as photos, videos, writing, etc. The interview data also showed that the students enjoy the process of using digital tools, especially in the designing brochure. It offers students an opportunity to enhance creativity in employing multimedia software to combine photography, video, images, sound, and text collaboratively. Therefore, the brochure becomes more exciting and informative.

The next negotiation of behavioral beliefs was oriented to students' positive beliefs toward creativity. Toward this entity, students felt more creative in creating a new product such as photos, videos, writing, and others. Using multimedia software to combine photography, video, images, sound, and text was considered entirely collaborative. The designing brochure project enhanced students' creativity because in combining all these components, creativity is needed so that the resulting product becomes more interesting and informative. The questionnaire continuously investigated students' beliefs about the benefits of integrating digital literacy related to online ethical awareness. This term is focused on sharing personal information. The interview data highlighted that students had a reasonably good awareness not to access or approach sites that contained pornographic content. 
Students prefer to ignore pop-up ads that implicitly contain pornography. By avoiding and ignoring pornography content, students expectedly had the awareness and filters not to access harmful content that was not suitable for them. Interview data pointed out that that all students had high self-awareness not to easily trust strangers, especially those they know from the Internet. All participants expressed their fears and concerns about the possible dangers of relying on and sharing their personal information to strangers they know via social media. Students seem to have self-awareness, allowing them to avoid the possibility of experiencing cybercrime.

\section{Increasing English Proficiency}

In terms of English proficiency, 95,8\% of students believed that the Internet and digital literacy facilitated them to master English. The interview revealed that most students used the Internet and digital literacy as a medium for safe and enjoyable entertainment and used as a facilitator to influence their English skills, such as mastering vocabularies, listening, speaking, writing, and even reading skills. Similarly, another student said that to increase her English skills especially for speaking, listening, and pronunciation skills, she often accessed Hollywood movies as an English learning alternative. Meanwhile, in reading and writing and reading skills, students tended to access online novel platforms, such as Wattpad or write on social media. In addition, students acquired more vocabularies using Internet resources. They claimed reading the English script; a lot found unfamiliar and complicated terms, terminologies, and idioms. When faced this situation, students will access Google Translate to understand the purpose of the intended narration.

\section{Students' normative beliefs}

In this section, the focus of the discussion was on the belief that an action was supported or not supported by a particular person, group, organization, or community and on the perception of control (Normative beliefs) (Ajzen, 1991). Based on the aspects of normative beliefs, students perceive that their environment (school), parents, teachers, and friends were fully aware that digital literacy was helpful and ended to support them.

Table 1. Close-ended questionnaires result of Students' normative beliefs

\begin{tabular}{ll}
\hline Survey Categories & Average \\
\hline School environment & $98.5 \%$ \\
Teachers & $100 \%$ \\
Parents & $95.8 \%$ \\
Peers & $98.5 \%$ \\
\hline
\end{tabular}

Based on Table 1, most of the students believed that school environment, teachers, parents, and peers' support played a vital role in integrating digital literacy into the EFL classroom. To integrate digital literacy into EFL classrooms, the support from the school certainly plays a significant role. Students believed that WiFi facilities that could be accessed by teachers and students were a form of support provided by the school. This is shown from the results of observations, where the teacher's laptop was directly connected to the school WiFi. In addition, the results of observations also reported that schools were equipped with supporting multimedia facilities such as LCD projectors, screens and sound systems. These facilities were not only used to support learning activities but also to support teachers to integrate digital technology by involving students in the use of digital technology in learning but also as an effort to keep the integration of digital literacy in the school environment.

In addition, questionnaire data revealed that the teacher takes the most vital role in students' normative beliefs. During the interview, the students mentioned that the teacher was one of the groups that most support them in integrating digital literacy. The students believed that it was considered beneficial for developing students' knowledge, increasing online ethical awareness, communication and expression skills, and mastery of English language skills. The observation data supported this data that teachers always involve 
students with digital tools in teaching and learning activities, ranging from simple ones such as using PPT presentations to complex ones such as manipulating photo and video application. Students believe that high interaction with digital tools in teaching and learning activities was a form of support provided by teachers who could open more significant opportunities to integrate digital literacy in learning media.

Meanwhile, during collected the data, it revealed that they received generous support from parents. The interview results showed that parents facilitate their children with smartphones and even a PC connected to the Internet either through prepaid or postpaid data $(\mathrm{WiFi})$ at home. Therefore, students can study anywhere and anytime without being limited by time and space. The students pointed out that the provision of facilities such as WiFi access, PCs, and smartphones was a form of support from parents to support the integration of digital literacy and the use of digital technology. In addition, from the interview, it was seen that the parents believed that students could use the Internet wisely according to their needs. Moreover, despite the advantages of integrating digital literacy into instructional media, students said that their parents were aware that the Internet might provide unnecessary, invalid, and false information. Therefore they warn their children to be more careful in receiving information from the Internet. Assessing, checking, and analyzing the validity of information is something that students must do. The attitude of parents who provide opportunities for students to interact with the Internet and digital technology without disturbing their privacy was assumed to be the right form of support in today's digital era.

\section{Students' control Beliefs}

Control beliefs component was related to measures of perceived behavioral control. Control beliefs suggested that the more opportunity the users got in their learning activities and the more access they have to resources, the greater their perceived control. The questionnaire result reflected that students believed that they can easily integrate digital literacy because of the availability of adequate facilities, both those that have been provided by schools and those provided by parents. Digital literacy is needed so that students can make the best use of digital tools that have been provided by schools and parents. In line with the availability of complete facilities, students also believed that the chance to use digital devices in learning also gives them more excellent opportunities to integrate digital literacy in the classroom. This result shows that besides the availability of digital devices, the chance to involve digital tools in learning also brings an excellent influence for students to integrate digital literacy. In other words, teacher support is needed to invite students to use the Internet and learning media and learning resources.

\section{Discussion}

This study revealed that students' behavioral beliefs were related to students' perception of the benefit of digital literacy. Those benefits were related to effectiveness and efficiency in searching information of material, cognitive skills and ethical awareness, and proficiency in English. The initial results show that most students integrated digital literacy into their EFL classroom due to the effectiveness and efficiency in searching information. Therefore, the students also found that digital technology and literacy is effective to share useful information they got with others, sent assignments, and discussed via digital. Due to its potential to seek information faster and contain completer information than the book could do, students prefer to utilize the Internet while looking for information. This finding is supported by pevious study which revealed that students relied on speed and found it difficult to tolerate a slow-paced environment; therefore, it can be understood why students prefer to use digital technology which is considered to be faster in providing information (Thompson, 2013).

Since digital literacy makes it easier for the students to understand the information presented via the Internet, the students started to integrate digital literacy into intructional media in EFL classroom. The information presented in simple language and sometimes followed by illustrations influenced the better understanding of the information (Wan, 2011). Previous research also supported this finding that concluded that students who enter through 
university EAP pathways with an explicit digital literacy focus had a better understanding of academic integrity practices and institutional policies and had less difficulty accessing course content (Roche, 2017). Contrary, other study reported in their study that it is not digital literacy that affects students' cognitive abilities, but on the contrary cognitive abilities affect students' digital literacy abilities (Syah et al., 2019 ). Despite the different results, it cannot be denied that digital literacy and students' cognitive skills are related.

In this component, apart from comparing the same information from different sources, other students revealed that accessing the website of trusted English language courses and quoting information from these sites can be an alternative to finding valid information. Since a reputable course institution maintains the website, it was unlikely that site administrators would provide incorrect information to its users. Relying on information from trusted sources is an option for students to find reliable information. Regarding this finding, almost all students of California state university begin the information search by trying to find an outline (essential points) of the available information, identify information relevant to the topic assigned to them, then students investigate and evaluate the information (Dunn, 2002). Most students even first look for information from websites, databases, and books and send emails to people they think might have information relevant to their topic. It means that a trusted website can be an alternative to getting accurate information. Moreover, digital literacy is used to increase media use efficiently in terms of information (Buckingham, 2015). For example, by developing information search skills (power search), users can find relevant and credible information amid a large amount of information available on the Internet. On the other side, another student relied on the source recommended by the teacher to find additional information related to the subject matter.

Moreover, students also noted that integrating digital literacy into their instructional media promoted the others cognitive skills; communication, creativity, critical thinking, separating false and correct information, selecting credible information, using specific technologies/applications to create a product, and gaining ethical awareness in the digital environment. This result is in line with previous result who suggested that integrating digital literacy into teaching and learning enhanced engagement, communication, and interaction, and improved skills beneficial for the future carrier (Lee, 2014). Other study also noted that base on the interview managed, some teacher's beliefs that were integrating digital literacy in the classroom help the students to encourage their critical thinking because the Internet full of misleading and fake information and students need to aware about that (Sadaf \& Gezer, 2020). In line, a comparative approach is considered quite useful to improve students' critical thinking skills (Fabos, 2004). Meanwhile, digital literacy, in terms of information, is used to increase the use of media efficiently (Buckingham, 2015). For example, by developing information search skills (power search) that will make it easier for users to find relevant and credible information amid a large amount of information available on the Internet.

In addition, the finding also showed that students tended to rely on what was provided by the teacher, including sources of information and keywords related to English materials. Teacher recommendations about sites that can be used as learning resources were also considered a practical step for students to avoid inaccurate or unsafe information. This finding is supported by previous study, who reported that to build a web search, teachers can provide information about how to do it, so students are more likely to find relevant information (Payton \& Hague, 2010). One of the other students' behavioral belief was the belief that digital literacy would increase students' English proficiency. In listening and speaking skills, for example, learners were able to imitate pronunciation, intonation, and expressions like native speakers do through previously selected YouTube shows, TED talk podcasts, music, or movies. This finding is supported by previous research which claimed that a group of young learners improve their speaking skills and sub-skills and improve their self-regulation through digital literacy in the process of learning English as a foreign language (EFL) (Soto et al., 2018). They also showed that the students enhanced their speaking skills, especially in terms of intonation, pronunciation, and level when expressing continuous actions. Meanwhile, in terms of writing, the employed digital literacy tools such as online applications or online novel platforms such as Wattpad and social media such as Whatsapp, Instagram, 
and Twitter were noted that the students could improve their writing skills in regards to grammar and vocabularies. This finding is similar to previous studies that claimed that the utilize of social media seemed to have benefited from the spell checker as they have received better scores in the area of spelling, vocabulary, grammatical accuracy, and writing fluency (Allagui, 2014; Rodliyah, 2016).

In terms of normative beliefs, it cannot be denied that support from those who closest to the students, such as parents, friends, teachers, and the school environment, has a vital role in students' normative beliefs. Teachers' role especially, had a fundamental influence in students' normative beliefs. Students felt motivated by the support provided by teachers and parents. The finding is supported by previous studies which found that instructors' or teachers' support, peers' opinions, and institutional promotion all play significant roles in students' decisions to use technology in learning (Huang et al., 2020). Similarly, the results of Unicef's research in collaboration with the Ministry of Communication and Information Technology show that communication patterns among children and adolescents via the Internet, which have a significant effect, are mostly done with peers, followed by communication with teachers, and communication with family members (Broto, 2014). Thus, it was not surprising that schools, friends, teachers, and parents influenced students' beliefs, because this environment was the closest to and most frequently interacting with students. On the other hand, what was more interesting about the results of the interview on normative beliefs was that despite those factors, the students admitted that the desire that came from oneself became one of the most influential factors of their intentions. In terms of control beliefs, the availability of facilities such as computers and internet networks, quality lessons, training. and opportunities to interact with digital literacy in the classroom were mentioned as a positive influence on students' intentions to integrate digital literacy (Kimbell-Lopez et al., 2016; Sadaf \& Gezer, 2020).

\section{Conclusions and Suggestions}

This study highlighted a substantive theory related to the findings: Students' positive beliefs about integrating digital literacy into EFL classroom influence students' learning strategy. By having positive beliefs about the outcomes that students will get (behavioral beliefs), support from family, teachers, and the school environment (normative beliefs), as well as beliefs about the presence of factors that may facilitate or hinder the performance (control beliefs), students demonstrate the tendency to always use digital technology in learning English. On the other hand, the students engaged as the research participants have positive beliefs toward integrating digital literacy into instructional media in the EFL classroom. Their positive response reflects their positive beliefs on the questionnaire, interviews, and observations related to the integration of digital literacy in instructional media. This belief highlights the need for teachers, parents and educators to support students in integrating digital literacy in their classrooms. As the main target of digital literacy, with the support, opportunities, and facilities provided by teachers, schools, and parents, this study helped students be more aware of digital technology and upgrade digital literacy competencies to prepare for their future. Nonetheless, in this study, only three students were involved as informants from one class in one school. Therefore, the authors suggest that further research involves a broader range of participants with different research contexts.

\section{References}

Abdi, H., \& Asadi, B. (2015). A Synopsis of Researches on Teachers' and Students' Beliefs about Language Learning. International Journal on Studies in English Language and Literature (IJSELL).

Ajzen, I. (1991). The theory of planned behavior. Organizational Behavior and Human Decision Processes. https://doi.org/10.1016/0749-5978(91)90020-T.

Ajzen, I. (2005). Attitudes, Personality and Behavior (Second Edition). In Open University Press. 
Alhamami, M. (2018). Beliefs about and intention to learn a foreign language in face-to-face and online settings. Computer Assisted Language Learning. https://doi.org/10.1080/09588221.2017.1387154.

Allagui, B. (2014). Writing through WhatsApp: An evaluation of students writing performance. In International Journal of Mobile Learning and Organisation. https://doi.org/10.1504/IJMLO.2014.067022.

Bekker, T., Bakker, S., Douma, I., van der Poel, J., \& Scheltenaar, K. (2015). Teaching children digital literacy through design-based learning with digital toolkits in schools. International Journal of Child-Computer Interaction. https://doi.org/10.1016/j.ijcci.2015.12.001.

Bordalba, M. M., \& Bochaca, J. G. (2019). Digital media for family-school communication? Parents' and teachers' beliefs. Computers and Education. https://doi.org/10.1016/j.compedu.2019.01.006.

Broto, G. S. D. (2014). Riset kominfo dan UNICEF mengenai perilaku anak dan remaja dalam menggunakan internet. In Siaran Pers No. 17/Pih/Kominfo/2/2014.

Buckingham, D. (2015). Defining digital literacy: What do young people need to know about digital media? Nordic Journal of Digital Literacy.

Cephe, P. T., \& Yalcin, C. G. (2015). Beliefs about foreign language learning: The effects of teacher beliefs on learner beliefs. Anthropologist. https://doi.org/10.1080/09720073.2015.11891651.

Chan, K. W., \& Elliott, R. G. (2004). Relational analysis of personal epistemology and conceptions about teaching and learning. Teaching and Teacher Education. https://doi.org/10.1016/j.tate.2004.09.002.

Dunn, K. (2002). Assessing information literacy skills in the California State University: A progres report. Journal of Academic Librarianship. https://doi.org/10.1016/S00991333(01)00281-6.

Eshet-Alkalai, Y. (2012). Thinking in the Digital Era: A Revised Model for Digital Literacy. Issues in Informing Science and Information Technology. https://doi.org/10.28945/1621.

Fabos, B. (2004). Giddy Prophesies and Commercial Ventures: The History of Educational Media. In Wrong Turn on the Information Superhighway: Education and the Commercialization of the Internet.

Ferrari, A. (2013). Digital Competence in Practice: An Analysis of Frameworks. Joint Research Centre of the European Commission. https://doi.org/10.2791/82116.

Furinghetti, F., \& Pehkonen, E. (2005). Rethinking Characterizations of Beliefs. In Beliefs: A Hidden Variable in Mathematics Education? https://doi.org/10.1007/0-306-47958-3_3.

Glaser, B. G., \& Strauss, A. L. (1967). Grounded theory The discovery of grounded theory. In International Journal of Qualitative Methods.

Hafner, C. A., Chik, A., \& Jones, R. H. (2015). Digital literacies and language learning. Language Learning and Technology.

Huang, F., Teo, T., \& Zhou, M. (2020). Chinese students' intentions to use the Internet-based technology for learning. Educational Technology Research and Development. https://doi.org/10.1007/s11423-019-09695-y.

Iordache, C., Mariën, I., \& Baelden, D. (2017). Developing digital skills and competences: A quick-scan analysis of 13 digital literacy models. Italian Journal of Sociology of Education. https://doi.org/10.14658/pupj-ijse-2017-1-2.

Karagiannopoulou, E., \& Christodoulides, P. (2005). The impact of Greek University students' perceptions of their learning environment on approaches to studying and academic outcomes. International Journal of Educational Research. https://doi.org/10.1016/j.ijer.2006.05.002.

Kimbell-Lopez, K., Cummins, C., \& Manning, E. (2016). Developing Digital Literacy in the Middle School Classroom. Computers in the Schools. https://doi.org/10.1080/07380569.2016.1249731.

Lee, S.-H. (2014). Digital Literacy Education for the Development of Digital Literacy. International Journal of Digital Literacy and Digital Competence. 
https://doi.org/10.4018/ijdldc.2014070103.

Lincoln, Y. S., \& Guba, E. G. (1985). Naturalist inquiry. In Beverly Hills, CA: Sage.

$\mathrm{Ng}, \mathrm{W}$. (2012). Can we teach digital natives digital literacy? Computers and Education. https://doi.org/10.1016/j.compedu.2012.04.016.

Payton, S., \& Hague, C. (2010). Digital Literacy Professional Development Resource. Development.

Richards, J. C., \& Lockhart, C. (1994). Reflective Teaching in Second Language Classrooms. In Reflective Teaching in Second Language Classrooms. https://doi.org/10.1017/cbo9780511667169.

Roche, T. (2017). Assessing the role of digital literacy in English for academic purposes university pathway programs. Journal of Academic Language and Learning.

Rodliyah, R. S. (2016). STUDENTS' WRITING. TEFLIN Journal - A Publication on the Teaching and Learning of English. https://doi.org/10.15639/teflinjournal.v27i1/82-100.

Sadaf, A., \& Gezer, T. (2020). Exploring factors that influence teachers' intentions to integrate digital literacy using the decomposed theory of planned behavior. Journal of Digital Learning in Teacher Education. https://doi.org/10.1080/21532974.2020.1719244.

Sadaf, A., \& Johnson, B. L. (2017). Teachers' Beliefs About Integrating Digital Literacy Into Classroom Practice: An Investigation Based on the Theory of Planned Behavior. Journal of Digital Learning in Teacher Education. https://doi.org/10.1080/21532974.2017.1347534.

Soto, A., Dary, L., Gutierrez, G., \& Andrea, Y. (2018). Digital Literacy and Basic SelfRegulation Habits in Early Childhood Learning of English as a Foreign Language. Folios. https://doi.org/10.17227/folios.49-9404.

Syah, R., Darmawan, D., \& Purnawan, A. (2019). Analisis Faktor yang Mempengaruhi Kemampuan Literasi Digital. Jurnal Akrab.

Thompson, P. (2013). The digital natives as learners: Technology use patterns and approaches to learning. Computers and Education. https://doi.org/10.1016/j.compedu.2012.12.022.

Wan, N. (2011). Why digital literacy is important for science teaching and learning. Teaching Science: The Journal of the Australian Science Teachers Association. 